\title{
Hunting of migratory birds in North Sinai, Egypt
}

\author{
PERRI EASON, BASEM RABIA and OMAR ATTUM
}

\section{Summary}

During autumn migration, people set trammel nets along most of the Mediterranean coast of Egypt, with migrating Common Quail Coturnix coturnix as their primary target. These nets capture large numbers of quail, but also illegally capture other birds, which are then killed. We present the results of surveys from 2008 to 2012 along these lines of nets on the coast of North Sinai, Egypt. In desert scrub, which covers most of the Sinai coast, the mean number of quail killed reached a high of 357.1 per $\mathrm{km}$ per day in 2012, with a grand mean over the study period of 191.9 per $\mathrm{km}$ per day. Trammel nets also captured 54 other bird species in 28 families. Species captured at the highest rates in desert scrub included Corncrake Crex crex, Isabelline Wheatear Oenanthe isabellina and Greater Short-toed Lark Calandrella brachydactyla. Based on mean rates of capture from 2008 to 2012 in desert scrub and sand bar habitats, we estimate 2.0 million quail and 0.5 million birds of other species are killed annually in North Sinai during the 45 days of peak migration. In 2012, however, after the use of $\mathrm{MP}_{3}$ players to attract quail became widespread, we estimate that 3.3 million quail and 0.5 million other birds were captured. Hunters near the coast have recently begun covering shrubs and trees with mist nets to catch passerines. From 2010 to 2012, mist nets along our survey routes caught birds of 17 species in three families, with seven of these species caught only in this type of net. Hunting is likely to be a contributing factor to population declines for some species that migrate across Egypt and further studies of migratory bird hunting along the southern Mediterranean shore are badly needed.

\section{Introduction}

Populations of Afro-Palearctic migrants are declining across Europe, and several studies have suggested that declines in this group are greater than declines in either short-distant migrants or permanent residents (Sanderson et al. 2006, Heldbjerg and Fox 2008, Thaxter et al. 2010). A recent review of these declines suggested that their primary causes were likely to be degradation of breeding and wintering habitats and climatic conditions on the wintering grounds (Vickery et al. 2014). That review also pointed out, however, that data which would enable us to assess the impact of hunting on Afro-Palearctic migrants are generally lacking.

Overhunting of migratory birds has long been a problem in countries along the Mediterranean Sea, and older estimates have suggested that one billion birds are killed there annually (Magnin 1991). There have been relatively few studies of hunting in North Africa, but one study based on recovered bands in the Maghreb of north-west Africa suggested that hunting pressure in this area was stronger than previously believed (McCulloch et al. 1992). In Egypt, people have been trapping migrating Common Quail Coturnix coturnix at least since the Old Kingdom (2650-2150 BCE; Magnin 1991). Although capturing quail may have once been primarily for subsistenceand many Bedouin are still subsistence hunters - quail have become a source of income for many hunters, with wild-caught quail often sold in markets as a seasonal delicacy and luxury food. 
During autumn migration, hunters now set nets along almost the entirety of Egypt's Mediterranean coastline, from the eastern border town of Rafah in northern Sinai, to the Libyan border town of Sallum in the west. They capture most quail with long lines of trammel nets. The nets, which are supported by poles set into the ground, typically catch birds from ground level to about $2.5 \mathrm{~m}$ in height. They are usually placed about $500 \mathrm{~m}$ from the shoreline on the mainland, as required by governmental regulations, and $3 \mathrm{~m}$ from the sea on sandbars.

In North Sinai, bird-hunting permits for autumn migration are provided by the North Sinai governorate specifically to capture quail, and these permits are typically renewed year after year to the same people. Regulations require permit holders to leave 10\% of their assigned area free of nets in order for some quail to pass through, e.g. a person who has a permit to hunt along $1,000 \mathrm{~m}$ of coastline should leave $100 \mathrm{~m}$ free from nets. Regulations also forbid taking birds other than quail. However, these rules are not enforced, and hunters regularly flout them. As a result, nets are typically immediately adjacent to one another. Furthermore, many migrant birds in addition to quail are captured in the nets (Baha el Din and Salama 1991), and hunters keep them all despite legal protection for migrants in Egypt. The fate of most of these birds is to be eaten, often by those who capture them or their families, but some are used as bait for catching other birds, and many are sold. Orioles, for example, may be used to attract other orioles, and they along with turtle doves, rails, and various small birds are sold at local markets (Baha el Din and Salama 1991) alongside the quail. Small falcons such as kestrels Falco tinnunculus are used as bait for larger falcons and may also be sold for this purpose.

Previous researchers have provided varied estimates about the numbers of birds captured by nets each autumn in Egypt, and there have been no recent published estimates. Most researchers that have worked in Egypt have focused on quail hunting. According to Goodman and Meininger (1989), Egypt exported 1-2 million quail annually from 1906 through 1913, but the annual catch probably was in the range of several hundred thousand per year by the mid-1980s. In 1972-1973, when quail netting was briefly banned in Sinai, quail hunters along the North Sinai coast continued to net birds using their traditional nets but then turned the quail over to biologists to be counted, yielding the most accurate estimates we have of quail hunting (Zuckerbrot et al. 1980). Zuckerbrot et al. (1980) calculated that 2.43 quail per net metre were captured over the entire autumn migration in 1972 , and 0.73 quail per net metre were captured during the 1973 migration. Baha al Din and Salama (1991) estimated that in North Sinai alone a minimum of 116,000 quails were captured over the 45-day migration season in autumn of 1989, with 205,000 captured in 1990. Baha al Din and Salama (1991) were the first to attempt to quantify losses of birds other than quail to the nets along the North Sinai coast. They estimated that 29,000 individuals of 16 identified species, plus Oenanthe sp. and Motacilla sp., were captured and killed in North Sinai in 1990.

Several innovations suggest that bird deaths may have increased since the earlier studies. Hunters began leaving nets open for 24 hours in the late 1980s (Baha al Din and Salama 1991), and in 2011 hunters began playing $\mathrm{MP}_{3}$ recordings of quails through the night to attract migrating quail to the nets, a technique that was common by 2012. In addition, in recent years hunters have placed mist nets in the same areas as the trammel nets specifically to target migrating passerines. Hunters cover trees and bushes with the mist nets, capturing small birds that avoid or escape the lines of trammel nets. In this study, which we conducted around Lake Bardawil in North Sinai, we provide the most complete information to date on the numbers of quail captured and the species and numbers of other birds that are trapped in the trammel nets, as well as in the nearby mist nets illegally set to catch passerines.

\section{Materials and methods}

Lake Bardawil is a hypersaline lagoon along the Mediterranean coast of North Sinai, Egypt (Figure 1). The habitat around the lake and along the entire North Sinai coast is primarily desert scrub, although Bardawil is separated from the Mediterranean Sea by a long, narrow sand bar that runs along its north shore. We surveyed birds captured in trammel nets near this lagoon each year 


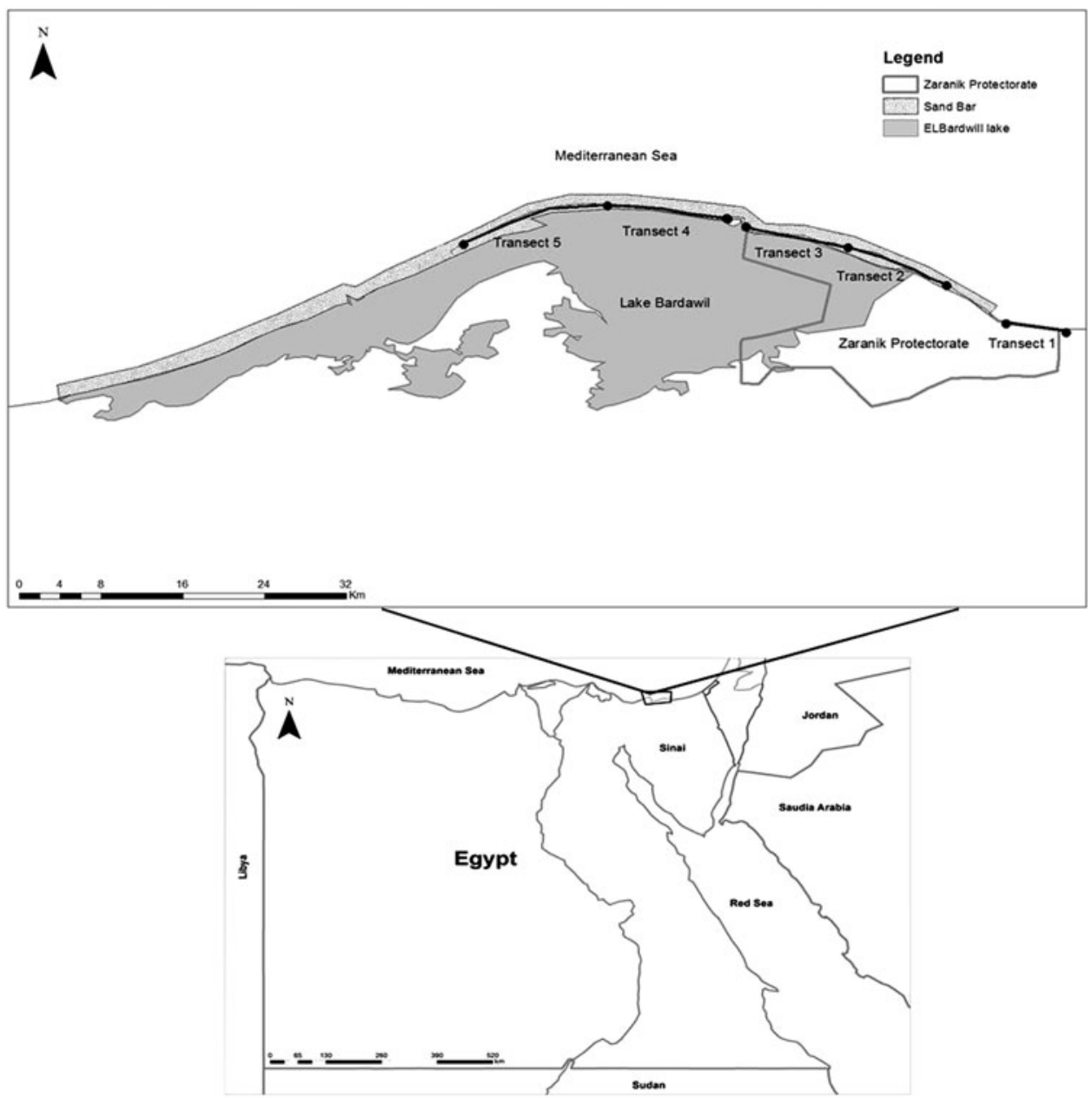

Figure 1. Map of Egypt with inset map showing Lake Bardawil and survey transects. Desert scrub surrounds the lake on all shores except the north, which consists of a sand bar that is indicated by speckling. Transect 1 was in desert scrub and transects 2-5 were in sand bar habitat.

from 2008 through 2012 during autumn migration, with survey dates from 1o September to 19 October. We mapped the survey routes using GPS, and we recorded the date, species, and number of birds captured along each transect.

To conduct our surveys, we walked along the lines of trammel nets that people had set in the desert scrub along the coast adjacent to Lake Bardawil and on the sand bars that separate Lake Bardawil from the Mediterranean. These nets have a variety of mesh sizes, but most have a panel with a small mesh of about $3 \times 3 \mathrm{~cm}$ and a second panel with a large mesh of about $17 \times 17 \mathrm{~cm}$. During our surveys, which we conducted from ophoo to Iohoo, we identified and counted birds that remained in the nets, and we asked people watching the nets to show us any other birds they had captured, which they often placed in coolers. All the people whom we asked agreed to show us their catches. Previous work showed that quail in North Sinai were captured by nets beginning 1o minutes after first light and continuing until o8hoo-10hoo (Zuckerbrot et al. 1980). Thus the captured quail that we counted would have been netted on the day we counted them. Our quail counts are likely to underestimate the numbers captured, as our surveys began while quail were 
still being netted. There is no possibility of doubly counting captured quail because they are collected daily by local traders who take them to markets to sell the same day. The timing of capture for other migrating species in North Sinai has not been described to our knowledge. Our trammel net counts for species other than quail would include birds captured from sunset, roughly ighoo, when hunters remove their catch from the nets for the evening, and the time of the survey. According to the hunters, most of these birds were captured in early morning hours. We questioned hunters about the date of capture for non-quail birds to reduce the possibility of doublecounting individuals; in addition, passerines are usually eaten within a day of capture by the bird hunters.

In 2008, the survey length was $5.04 \mathrm{~km}$ in desert scrub just east of Lake Bardawil (transect 1 ; see Figure $I$ for location and Table $I$ for list of transect surveys). In subsequent years we added four new survey routes, all along the sandy bar on the north side of Lake Bardawil. We added transect 2 (9.08 km long) in 2009, transect $3(8.61 \mathrm{~km})$ in 2010, transect $4(10.12 \mathrm{~km})$ in 2011 , and transect $5(12.62 \mathrm{~km})$ in 2012 . As the number of transects increased, the number of times we visited each route declined. For years in which we sampled more than one sand bar transect (2010-2012), we used all surveys on sand bars to calculate the mean numbers of birds captured in that habitat. For example, in 2012 six surveys were used to calculate the numbers of birds captured per kilometre on sand bars, two surveys each for transects 2, 3, and 4 (see Table 1 ). Once added to our study, each survey route was sampled twice per year with the following exceptions: transect 1 was surveyed 10 times in 2008, four times in 2009, and three times in both 2010 and 2011; transect 2 was surveyed three times in 2009; and transect 4 was surveyed four times in 2012. Means are reported \pm SE.

From 2010 to 2012 we also recorded the number and species of passerine birds captured in the mist nets that covered trees and shrubs along our survey route. The number and coverage of these nets depended on the amount of vegetation present. We did not record vegetation density or number of nets, but all bushes above $1 \mathrm{~m}$ in height and all trees were covered with nets on our survey routes. These surveys occurred between o7hoo and Iohoo from 1o September to II October. In 2010 and 2011 we surveyed mist nets along transect 1 (desert scrub) three times and along transects 2 and 3 twice each. In 2012, we surveyed mist nets along transects 1, 2, 3, and 5 twice, and along transect 4 four times. We counted birds trapped in the nets and in small cages adjacent to the nets where hunters stored birds removed from the nets for consumption later that day. As was the case with the trammel nets, according to hunters most birds were captured in the mist nets in the morning. Our recorded numbers may undercount the total numbers of passerines captured, if hunters had already consumed some of the birds, but the effect should be small as birds were generally eaten later in the day.

From our survey data, we calculated the mean capture rate of birds each year in the two habitats, desert scrub and sand bar, and then calculated a grand mean for each habitat from 2008 to 2012. To estimate the numbers of birds captured by trammel nets in all of North Sinai, we first mapped and measured the distances along which people set nets in desert scrub ( $168 \mathrm{~km}$ ) and on the Lake Bardawil sand bar (102 km). The distance for desert scrub includes coastline as well as

Table 1. Transect number, length, and number of times that trammel nets were sampled along these transects per year.

\begin{tabular}{|c|c|c|c|c|c|c|}
\hline \multirow[t]{2}{*}{ Transect } & \multirow[t]{2}{*}{ Length in $\mathrm{km}$} & \multicolumn{5}{|c|}{ Number of Samples per Transect } \\
\hline & & 2008 & 2009 & 2010 & 2011 & 2012 \\
\hline 1 & 5.04 & 10 & 4 & 3 & 3 & 2 \\
\hline 2 & 9.08 & - & 3 & 2 & 2 & 2 \\
\hline 3 & 8.61 & - & - & 2 & 2 & 2 \\
\hline 4 & 10.12 & - & - & - & 2 & 4 \\
\hline 5 & 12.62 & - & - & - & - & 2 \\
\hline
\end{tabular}


the inland shore of Lake Bardawil, along which hunters place nets where it runs approximately east-west. We then calculated the numbers of birds typically captured on one day in each habitat, summed the two numbers, and then multiplied the result by 45 days, which is the length of the peak migration period. We also estimated the total numbers of quail and other birds captured for the Egyptian Mediterranean coastline, a calculation for which we used an estimate of $800 \mathrm{~km}$ of nets along the coast outside North Sinai. This estimate is based on reports that essentially the entire coastline is netted, including many urban areas.

\section{Results}

The trammel nets caught substantial numbers of quail (Fig 2). The mean rate of quail capture on the sand bar between Lake Bardawil and the Mediterranean Sea ranged from a low of 42.5 ( \pm 5.1) individuals per $\mathrm{km}$ per day in 2009 to a high of $202.0( \pm 49.9)$ per $\mathrm{km}$ per day in 2011, with no overall trend. Mean rates of quail caught in desert scrub were higher and increased annually, from a low of 77.6 ( \pm 12.5$)$ per km per day in 2008 to a high of 357.1 ( \pm 138.9$)$ per km per day in 2012.

These nets also captured large numbers of passerines and other non-quail birds (Figure 3 ). Excluding quail, over the five-year study period a total of 13,229 birds were captured along our survey transects (Table 2). These birds belonged to 54 species and 28 different families, and 45 of these species were captured only in trammel nets. The mean rate of captures of non-quail birds was consistently higher in desert scrub than along the sand bar. In desert scrub the most birds were captured in 2010, with a mean of 76.3 ( \pm 32.1 ) birds captured per km per day, and the fewest were killed in 2008 (mean $=30.3 \pm 4.1$ birds per $\mathrm{km}$ per day). Along the sand bar, the mean number captured ranged from a low of $25.6( \pm 5.1)$ in 2011 to a high of $58.7( \pm 11.8)$ in 2010.

The total numbers captured of each species and their mean rates of capture are shown in Table 2. The species killed in largest numbers in the trammel nets over the course of this study (i.e. a total for 5 years of the survey) included Corncrakes Crex crex, 3,108 individuals; Greater Short-toed Larks Calandrella brachydactyla, 2,432 individuals; Isabelline Wheatears Oenanthe isabellina, 2,III individuals; and Thrush Nightingales Luscinia luscinia, 840 individuals.

Predatory birds were also captured in these nets, presumably because they were attracted to already captured birds. Shrikes as a group were particularly vulnerable. Shrike species that were

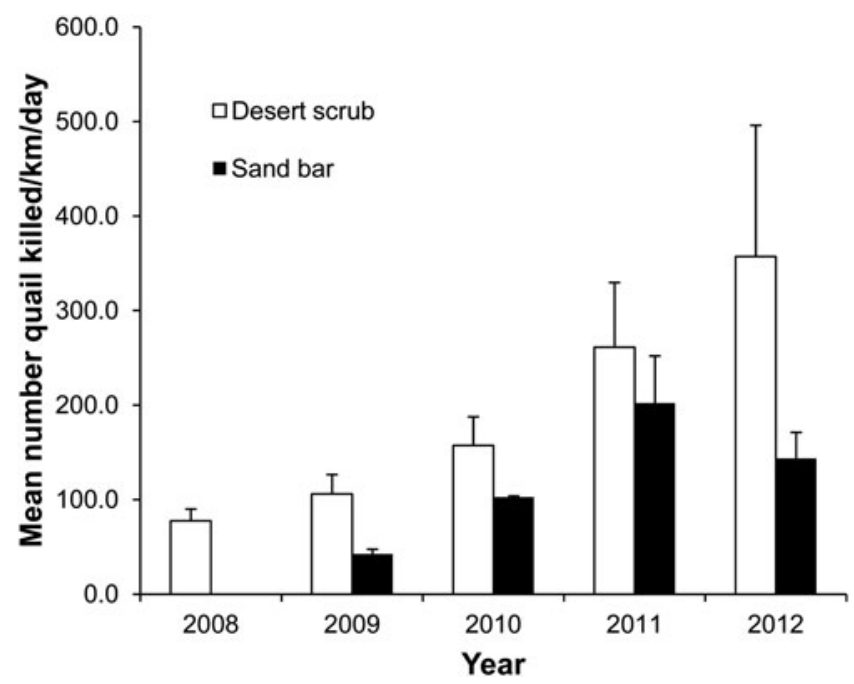

Figure 2. Mean $( \pm \mathrm{SE})$ number of Common Quail killed per km per day in surveys on the sand bar and in desert scrub habitat from 2008 to 2012. 


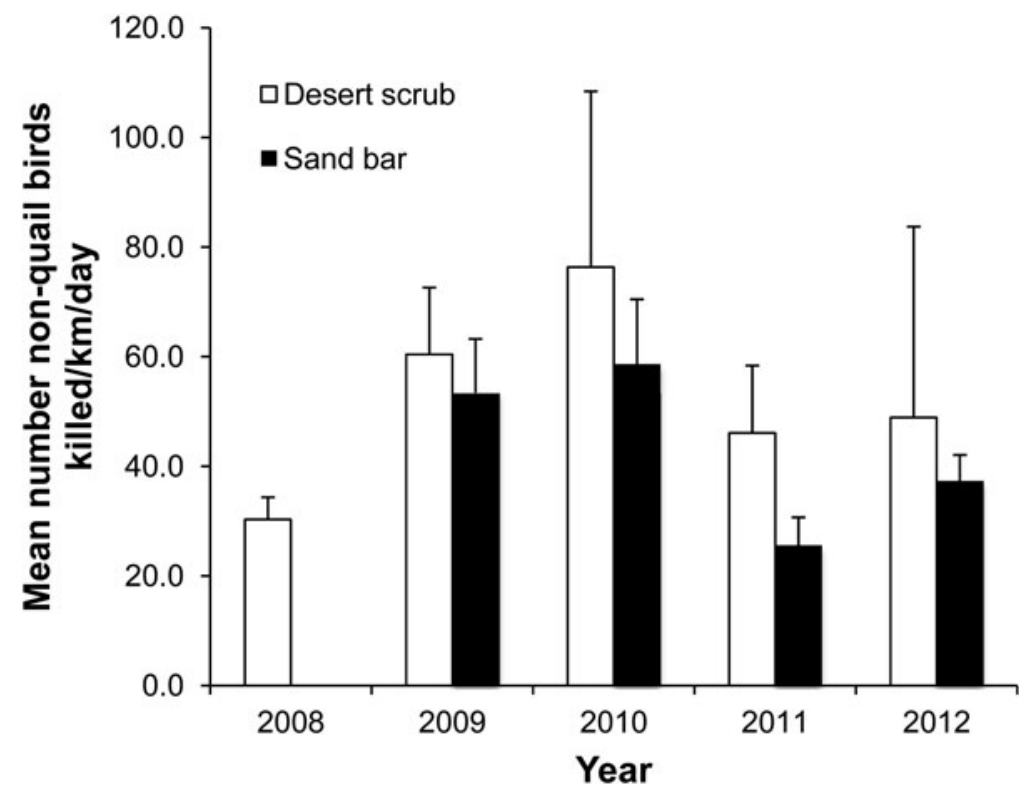

Figure 3. Mean number $( \pm$ SE) of birds other than Common Quail killed per km per day on the sand bar and in desert scrub habitat in surveys from 2008 to 2012.

killed included the Red-backed shrike Lanius collurio, 595 individuals; Great Grey Shrike Lanius excubitor, I17 individuals; Lesser Grey Shrike Lanius minor, II individuals; and Woodchat Shrike Lanius senator, 8 individuals. Raptors were killed in relatively low numbers. These included three species of owls, Common Scops Owl Otus scops, 3 individuals; Little Owl Athene noctua, 1o individuals; and Long-eared Owl Asia otus, I individual. Diurnal raptors that were captured included six Lesser Kestrels Falco naumanni, four threatened Red-footed Falcons F. vespertinus, two Hobbies F. subbuteo, and I Black Kite Milvus migrans.

Based on our survey data, we estimated that a total of 2.6 million birds were captured each year in trammel nets on North Sinai coasts during the 45 days of peak migration (Table 2). Of these, 2.o million were quail and the remaining 0.6 million were other bird species. Using only the rates of capture from 2012, the most recent year of our survey, we estimate that 3.9 million birds were captured in North Sinai that year, 3.4 million quail and 0.5 million birds of other species. This estimate assumes capture rates on average are equal across the northern Sinai coast, which may not be the case; capture rates could vary due to migratory pathways, urbanisation or small-scale agriculture.

The mist nets specifically targeting passerines captured no birds when placed in desert scrub (Table 3). However, nets on sand bars were more successful, with a total of 667 birds captured between 2010 and 2012 on 18 survey days, with each survey covering between 8.61 and $12.62 \mathrm{~km}$. Seventeen species in three families were captured in these nets (Table 3). Of these, seven species were captured only in this kind of net, and to had not previously been reported having been captured by illegal mist-netting in Egypt. The most commonly captured species were Thrush Nightingale Luscinia luscinia, Lesser Whitethroat Sylvia curruca, Whitethroat S. communis, and Willow Warbler Phylloscopus collybita, which together accounted for $51.4 \%$ of the total.

\section{Discussion}

Our results suggest that enormous numbers of birds die in the nets set along the Egyptian coastline during autumn migration. We identified a total of 62 species that people captured with nets. Of these species, 45 were captured only in the trammel nets, and seven were captured only in the 
Table 2. Species captured in trammel nets, rates at which they were captured per km per day in two habitats, total captured in 2008-2012 surveys, and annual catch estimate for North Sinai. The * symbol indicates species only caught in trammel nets, and t indicates species not previously recorded as captured in these nets in Egypt.

\begin{tabular}{|c|c|c|c|c|c|}
\hline Family/common name & Scientific name & Desert scrub & Sand bar & Total & North Sinai estimate \\
\hline \multicolumn{6}{|l|}{ Phasianidae } \\
\hline${ }^{*}$ Common Quail & Coturnix coturnix & $191.88 \pm 51.84$ & $122.64 \pm 29.14$ & 41,963 & $2,013,569$ \\
\hline \multicolumn{6}{|l|}{ Ardeidae } \\
\hline${ }^{*}+$ Little Bittern & Ixobrychus minutus & $\mathrm{o}$ & - & 1 & 115 \\
\hline \multicolumn{6}{|l|}{ Pelecanidae } \\
\hline${ }^{*}+$ White Pelican & Pelecanus onocrotalus & $\mathrm{o}$ & $0.01 \pm 0.01$ & 1 & 33 \\
\hline \multicolumn{6}{|l|}{ Falconidae } \\
\hline${ }^{*}+$ Lesser Kestrel & Falco naumanni & $0.02 \pm 0.01$ & $0.03 \pm 0.02$ & 6 & 303 \\
\hline *+Common Kestrel & Falco tinnunculus & $0.02 \pm 0.01$ & $0.05 \pm 0.01$ & 10 & 353 \\
\hline${ }^{*}+$ Red-footed Falcon & Falco vespertinus & $0.02 \pm 0.01$ & $0.01 \pm 0.01$ & 4 & 192 \\
\hline$*$ +Hobby & Falco subbuteo & $0.01 \pm 0.01$ & $0.01 \pm 0.01$ & 2 & 107 \\
\hline \multicolumn{6}{|l|}{ Accipitridae } \\
\hline${ }^{*}+$ Black Kite & Milous migrans & $0.01 \pm 0.01$ & o & 1 & 100 \\
\hline \multicolumn{6}{|l|}{ Rallidae } \\
\hline${ }^{*}$ Water Rail & Rallus aquaticus & $0.24 \pm 0.08$ & $0.24 \pm 0.07$ & 92 & 2,940 \\
\hline${ }^{*}$ Corncrake & Crex crex & $15.28 \pm 5.11$ & $7.92 \pm 1.96$ & 3,108 & 151,872 \\
\hline${ }^{*}+$ Little Crake & Porzana parva & $0.06 \pm 0.03$ & $0.04 \pm 0.02$ & 13 & 629 \\
\hline${ }^{*}$ Spotted Crake & Porzana porzana & $0.03 \pm 0.03$ & $0.05 \pm 0.03$ & 17 & 427 \\
\hline${ }^{*}$ Common Moorhen & Gallinula chloropus & $0.11 \pm 0.07$ & $0.28 \pm 0.11$ & 79 & 2,070 \\
\hline \multicolumn{6}{|l|}{ Burhinidae } \\
\hline${ }^{*}$ EurasianThick-knee & Burhinus oedicnemus & $0.04 \pm 0.04$ & $0.03 \pm 0.02$ & 13 & 459 \\
\hline \multicolumn{6}{|l|}{ Charadriidae } \\
\hline${ }^{*}+$ Kentish Plover & Charadrius alexandrinus & $\mathrm{o}$ & $0.01 \pm 0.01$ & 2 & 72 \\
\hline \multicolumn{6}{|l|}{ Scolopacidae } \\
\hline${ }^{*}+$ Sanderling & Calidris alba & $0.03 \pm 0.02$ & $0.01 \pm 0.01$ & 4 & 292 \\
\hline \multicolumn{6}{|l|}{ Columbidae } \\
\hline${ }^{*}$ European Turtle-dove & Streptopelia turtur & $3.24 \pm 0.47$ & $2.18 \pm 0.34$ & 840 & 34,534 \\
\hline \multicolumn{6}{|l|}{ Cuculidae } \\
\hline${ }^{*}$ tGreat Spotted Cuckoo & Clamator glandarius & o & $0.04 \pm 0.02$ & 7 & 206 \\
\hline${ }^{*}$ Common Cuckoo & Cuculus canorus & $0.16 \pm 0.08$ & $0.13 \pm 0.02$ & 44 & 1,769 \\
\hline
\end{tabular}


Table 2. Continued.

\begin{tabular}{|c|c|c|c|c|c|}
\hline Family/common name & Scientific name & Desert scrub & Sand bar & Total & North Sinai estimate \\
\hline \multicolumn{6}{|l|}{ Strigidae } \\
\hline${ }^{*}$ Common Scops-owl & Otus scops & o & $0.01 \pm 0.01$ & 3 & 54 \\
\hline${ }^{*}+$ Little Owl & Athene noctua & o & $0.06 \pm 0.05$ & 10 & 297 \\
\hline${ }^{*}+$ Long-eared Owl & Asio otus & o & $0.01 \pm 0.01$ & 1 & 32 \\
\hline \multicolumn{6}{|l|}{ Caprimulgidae } \\
\hline${ }^{*}$ Eurasian Nightjar & Caprimulgus europaeus & $0.35 \pm 0.12$ & $0.54 \pm 0.09$ & 131 & 5,111 \\
\hline \multicolumn{6}{|l|}{ Coraciidae } \\
\hline${ }^{*}$ European Roller & Coracias garrulus & $0.04 \pm 0.02$ & $0.04 \pm 0.01$ & 9 & 463 \\
\hline \multicolumn{6}{|l|}{ Alcedinidae } \\
\hline${ }^{*}$ Common Kingfisher & Alcedo atthis & $2.10 \pm 0.94$ & $1.34 \pm 0.46$ & 384 & 22,014 \\
\hline \multicolumn{6}{|l|}{ Meropidae } \\
\hline *European Bee-eater & Merops apiaster & $0.17 \pm 0.12$ & $0.44 \pm 0.15$ & 104 & 3,316 \\
\hline \multicolumn{6}{|l|}{ Upupidae } \\
\hline${ }^{*}$ Eurasian Hoopoe & Upupa epops & $2.94 \pm 0.79$ & $1.95 \pm 0.60$ & 596 & 31,172 \\
\hline \multicolumn{6}{|l|}{ Picidae } \\
\hline${ }^{*}$ Eurasian Wryneck & Jynx torquilla & $0.68 \pm 0.55$ & $0.75 \pm 0.50$ & 298 & 8,597 \\
\hline \multicolumn{6}{|l|}{ Laniidae } \\
\hline${ }^{*}$ Red-backed Shrike & Lanius collurio & $2.33 \pm 0.70$ & $2.22 \pm 0.43$ & 595 & 27,792 \\
\hline *+Lesser Grey Shrike & Lanius minor & $0.03 \pm 0.03$ & $0.04 \pm 0.02$ & 11 & 386 \\
\hline${ }^{*}+$ Great Grey Shrike & Lanius excubitor & $0.18 \pm 0.08$ & $0.39 \pm 0.12$ & 117 & 3,147 \\
\hline *+Woodchat Shrike & Lanius senator & $0.02 \pm 0.02$ & $0.04 \pm 0.02$ & 8 & 314 \\
\hline \multicolumn{6}{|l|}{ Oriolidae } \\
\hline${ }^{*}$ Eurasian Golden Oriole & Oriolus oriolus & $0.03 \pm 0.02$ & $0.03 \pm 0.01$ & 10 & 351 \\
\hline \multicolumn{6}{|l|}{ Hirudinidae } \\
\hline *Sand Martin & Riparia riparia & $0.04 \pm 0.04$ & $0.12 \pm 0.04$ & 22 & 861 \\
\hline *Barn Swallow & Hirundo rustica & $0.87 \pm 0.38$ & $0.46 \pm 0.10$ & 233 & 8,702 \\
\hline \multicolumn{6}{|l|}{ Alaudidae } \\
\hline${ }^{*}$ Greater Short-toed Lark & Calandrella brachydactyla & $7.49 \pm 3.20$ & $10.50 \pm 4.31$ & 2,432 & 104,817 \\
\hline${ }^{*}+$ Crested Lark & Galerida cristata & $0.03 \pm 0.02$ & $0.06 \pm 0.04$ & 11 & 467 \\
\hline \multicolumn{6}{|l|}{ Pycnonotidae } \\
\hline *+White-spectacled bulbul & Pycnonotus xanthopygos & $0.04 \pm 0.04$ & o & 3 & 300 \\
\hline
\end{tabular}


Table 2. Continued.

\begin{tabular}{|c|c|c|c|c|c|}
\hline Family/common name & Scientific name & Desert scrub & Sand bar & Total & North Sinai estimate \\
\hline \multicolumn{6}{|l|}{ Sylviidae } \\
\hline Great Reed Warbler & Acrocephalus arundinaceus & o & - & 2 & 23 \\
\hline Willow Warbler & Phylloscopus trochilus & $0.27 \pm 0.17$ & $0.59 \pm 0.15$ & 106 & 4,748 \\
\hline tCommon Chiffchaff & Phylloscopus collybita & o & $0.01 \pm 0.01$ & 4 & 41 \\
\hline Lesser Whitethroat & Sylvia curruca & o & $0.02 \pm 0.01$ & 6 & 74 \\
\hline tRueppell's Warbler & Sylvia rueppelli & $0.04 \pm 0.04$ & $0.01 \pm 0.01$ & 5 & 340 \\
\hline \multicolumn{6}{|l|}{ Turdidae } \\
\hline${ }^{*}+$ Eurasian Blackbird & Turdus merula & $0.10 \pm 0.06$ & $0.03 \pm 0.01$ & 14 & 896 \\
\hline \multicolumn{6}{|l|}{ Muscicapidae } \\
\hline Thrush Nightingale & Luscinia luscinia & $3.25 \pm 2.47$ & $4.80 \pm 1.10$ & 1,272 & 46,588 \\
\hline tCommon Nightingale & Luscinia megarhynchos & o & $0.07 \pm 0.05$ & 12 & 322 \\
\hline Common Redstart & Phoenicurus phoenicurus & $1.20 \pm 0.50$ & $0.51 \pm 0.15$ & 202 & 11,374 \\
\hline tWhinchat & Saxicola rubetra & $0.06 \pm 0.04$ & $0.22 \pm 0.09$ & 51 & 1,443 \\
\hline${ }^{*}$ Black-eared Wheatear & Oenanthe hispanica & $0.16 \pm 0.12$ & $0.31 \pm 0.12$ & 65 & 2,605 \\
\hline *Desert Wheatear & Oenanthe deserti & $0.34 \pm 0.16$ & $0.17 \pm 0.03$ & 64 & 3,338 \\
\hline *Isabelline Wheatear & Oenanthe isabellina & $9.91 \pm 1.85$ & $6.65 \pm 1.88$ & 2,111 & 105,491 \\
\hline \multicolumn{6}{|l|}{ Motacillidae } \\
\hline *+White Wagtail & Motacilla alba & $0.03 \pm 0.03$ & o & 4 & 260 \\
\hline *Yellow Wagtail & Motacilla flava & $0.39 \pm 0.13$ & $0.27 \pm 0.18$ & 74 & 4,230 \\
\hline${ }^{*}$ Tawny Pipit & Anthus campestris & $0.07 \pm 0.07$ & $0.05 \pm 0.04$ & 12 & 736 \\
\hline \multicolumn{6}{|l|}{ Emberizidae } \\
\hline Ortolan Bunting & Emberiza hortulana & o & $0.01 \pm 0.01$ & 3 & 34 \\
\hline Total non-quail birds & & & & 13,229 & 597,207 \\
\hline Total all birds & & & & 55,192 & $2,610,776$ \\
\hline
\end{tabular}


Table 3. Species captured in fine-mesh nets on trees and shrubs. Birds captured only in this type of net are indicated with an asterisk. Species not previously reported killed in nets along the Egyptian coast are marked with the symbol ' $t$ '.

\begin{tabular}{|c|c|c|c|}
\hline Common name & Scientific name & Total & Deaths/10o km/day \\
\hline \multicolumn{4}{|l|}{ Sylviidae } \\
\hline *+Savi's Warbler & Locustella luscinioides & 3 & 1.7 \\
\hline tGreat Reed Warbler & Acrocephalus arundinaceus & 6 & 3.5 \\
\hline${ }^{*}+$ Moustached Warbler & Acrocephalus melagopogon & 1 & 0.6 \\
\hline Willow Warbler & Phylloscopus trochilus & 80 & 46.5 \\
\hline tCommon Chiffchaff & Phylloscopus collybita & 53 & 30.8 \\
\hline *+Blackcap & Sylvia atricapilla & 57 & 33.2 \\
\hline *+Barred Warbler & Sylvia nisoria & 8 & 4.7 \\
\hline Lesser Whitethroat & Sylvia curruca & 88 & 51.2 \\
\hline${ }^{*}$ Greater Whitethroat & Sylvia communis & 72 & 41.9 \\
\hline tRüppell's Warbler & Sylvia rueppelli & 55 & 32.0 \\
\hline \multicolumn{4}{|l|}{ Muscicapidae } \\
\hline Thrush Nightingale & Luscinia luscinia & 103 & 59.9 \\
\hline Common Nightingale & Luscinia megarhynchos & 48 & 27.9 \\
\hline Common Redstart & Phoenicurus phoenicurus & 56 & 32.6 \\
\hline tWhinchat & Saxicola rubetra & 25 & 14.5 \\
\hline${ }^{*}+$ Collared Flycatcher & Ficedula albicollis & 4 & 2.3 \\
\hline${ }^{*}+$ Semi-collared Flycatcher & Ficedula semitorquata & 3 & 1.7 \\
\hline \multicolumn{4}{|l|}{ Emberizidae } \\
\hline Ortolan Bunting & Emberiza cineracea & 5 & 2.9 \\
\hline
\end{tabular}

mist nets that were wrapped over bushes and trees to target passerines, with the remaining 10 species captured in both kinds of nets. This study adds 32 species to those known to be illegally hunted along the Egyptian coast during migration, adds rates of capture for 38 species, and provides the best current estimate for quail and other bird hunting with trammel nets in the region. The previous survey of bird hunting in desert scrub in the North Sinai in 1989-1990 by Baha el Din and Salama (1991) combined numbers of birds caught in the trammel nets along the shore and birds caught by 'toraha', a weighted throw-net that is most often used to catch birds other than quail (Baha el Din and Salama 1991), making it impossible to assess the effects of trammel nets alone from that study. In addition that study was conducted by having bird hunters report their catch, a method that the authors found to cause some imprecision in identification and to underestimate catches of smaller birds. These factors make direct comparisons with our study difficult. Nonetheless, we can gain some understanding of the changes in hunting pressure on birds migrating across the Sinai by considering only larger species, for which the earlier estimates are likely to be accurate (Baha el Din and Salama 1991).

For those larger species for which at least four individuals were captured in the earlier study, our capture rate in desert scrub was 109.1 times greater for Corncrake, 7.9 times greater for European Turtle Dove Streptopelia turtur, 12.3 times greater for Common Kingfisher Alcedo atthis, and 4.7 times greater for Eurasian Hoopoe Upupa epops. Our capture rate for Eurasian Nightjar Caprimulgus europaeus, however, was only o.7 times that of the earlier rate, which may reflect overall declines in that species (del Hoyo et al. 1999), or declines in those populations that use the migration route through North Sinai. For the larger species for which only $1-2$ individuals were captured in the 1990 study (Baha el Din and Salama 1991), our capture rate in scrub was 8.o times higher for Water Rail Rallus aquaticus, 3.7 times higher for Common Moorhen Gallinula chloropus, 2.3 times higher for Common Cuckoo Cuculus canorus, and 9.7 times higher for Eurasian Wryneck Jynx torquilla. Thus for all comparable species except the Eurasian Nightjar, capture rates have at least doubled, and often they have increased dramatically. These substantial increases are surprising, given that we are comparing our rates to rates that included captures by toraha. 
In the earlier study toraha were found to catch close to as many non-quail birds as did the long nets and were particularly good for catching rails, crakes, Turtle Doves, and hoopoes (Baha el Din and Salama, 1991), which are some of the species we are using for comparison. If toraha are still being used at similar rates, numbers of captured birds have increased hugely since 1990.

Previous studies of netting birds in Egypt during migration have considered non-quail birds as bycatch. In the present study, $24 \%$ of birds captured in the trammel nets were species other than quail. This relatively high percentage suggests that we should consider all migrating birds as targets of present-day hunters. This idea is supported by the hunters' use of all these birds, and by the recent development of hunters setting mist nets specifically to catch migrating passerines. These nets are not as effective as trammel nets in terms of the numbers of birds captured; however, in this study they did capture several species that were not caught in trammel nets, and caught some species at relatively high rates.

The number of Common Quail captured in the scrub along the northern Sinai coast has similarly increased. The study by Zuckerbrot et al. (1980) provided accurate records of quail capture, but due to wide variation in numbers captured per day did not report mean values. However, as mentioned previously, that study determined that 2.43 and 0.73 quail were captured per metre of net over the entire migration season in 1972 and 1973, respectively. Since then, the mean number of quail captured each day per $\mathrm{km}$ per has risen from 14.1 in 1989, to 25.4 in 1990 (Baha el Din and Salama 1991) to 77.6 per km per day in 2008 (this study), and it reached a high of 357.1 in 2012 (this study).

Based on the mean capture rate during our study, we estimate that 2.0 million quail were captured annually in northern Sinai during the 45 days of peak autumn migration. In 2012, the year with highest capture rates for quail, we estimate 3.4 million quail were captured there during migration. If capture rates are similar along the rest of the Egyptian coast, which is similarly covered by nets during autumn migration, then an estimate based on our numbers from 2012 would suggest that 12.9 million quail were captured that year in Egypt. For comparison, a recent estimate suggests that the breeding population of Common Quail in Europe is between 8.4 and I4.I million birds (BirdLife International 2004). Earlier estimates of annual deaths of quail in North Sinai ranged from 70,000 (in 1981), to 150,000-200,000 in the 1960s, and 250,000 in 1925 and 1926 (Moreau 1927; reports cited in Baha el Din and Salama 1991). Clearly, current numbers of quail captured and killed are far higher. The Common Quail is not a species of conservation concern at present, in part because of its large geographic range. However, populations are believed to be declining (BirdLife International 2004), and hunting on the scale described here is likely to cause declines in European populations of this species.

The numbers of quail killed during autumn migration have increased in part because the distance nets cover and the amount of time they are left open have also increased over time. In the mid-1980s, nets were set along approximately $70 \mathrm{~km}$ of the North Sinai Coast (Goodman and Meininger 1989). By 1990, almost the entire coast was lined with nets, including most residential areas (Baha el Din and Salama 1991), and today nets are placed at any site where birds may be captured, including towns and the Zaranik Protectorate reserve. Approaching birds are not able to evade nets by going around their ends, since the nets are immediately adjacent to one another. Another factor in the increase in quail killed in 2011 and 2012 may be hunters' increasing use of $\mathrm{MP}_{3}$ recordings of quail calls to attract birds to nets, although these recordings are used both on the sand bar and in desert scrub, and capture rates did not increase on the sand bar, perhaps because of differences in vegetative cover. It is not known whether these calls also attract other species.

The numbers of migrating birds being captured as they reach North Sinai cannot be sustainable, and current conservation efforts in Europe for some of the bird species that fly over Egypt are likely to be ineffective, given the high hunting pressure during migration. A number of approaches could be used to alleviate the damage that illegal hunting is doing to bird populations, but of these improving education is the most important. Without a long-term effort to give Egyptians pride in the rich biological abundance of their nation, the Egyptian people will continue to view birds only 
as sources of food, which was the fate of almost all of the birds we saw, or as bait for catching other birds, or profit.

Another approach to solving the problem of illegal hunting and overhunting is hiring some bird hunters as guides. This may be precluded at present by the recent political upheavals which have caused immediate changes in tourism in Egypt, including a reduction in visitor numbers by about a third and a tendency for tourists to stay in resorts rather than explore the country. In future, however, Sinai has the potential to re-develop a strong tourist industry and to promote ecotourism. Just the presence of greater numbers of tourists, even if they are disinterested in the environment, may produce more restrictions on illegal hunting, as nets are currently placed even on the grounds of hotels and the sight of dying and dead songbirds will probably result in complaints to managers who will then have motivation at least to remove nets from the immediate vicinity of the hotels.

The capture of birds other than quail could potentially be reduced for the smaller bird species if the government or conservation organizations provided nets with larger mesh sizes to hunters in exchange for their current nets. There are hazards in this approach, however, as hunters could overlay such nets or add lines within them, ending up with new nets and a smaller effective mesh size.

Other potential approaches depend on enforcement that is not now being carried out. Better regulation of hunting is essential, as is the enforcement of the environmental laws already in effect in Egypt, which require, for example, spacing between quail nets to allow some birds to escape. It is difficult to determine whether too many hunting permits are awarded, as showing a permit is nowhere required. Ideally, at least for the present, no-hunting zones would be set up, as this is likely to be easier to enforce than net-spacing regulations.

Recent studies have noted the disproportionately large declines in populations of AfroPalearctic migrants (reviewed by Vickery et al. 2014) compared to resident species and shortdistance migrants. Although hunting may not be the primary cause of population declines for many species (Vickery et al. 2014), it is likely to be a contributing factor, given the large numbers of some species killed by hunters during the course of this study. Our current understanding of hunting's impacts is poor (Vickery et al. 2014), and the effects of hunting may be underestimated. More data on hunting in the southern Mediterranean regions would be particularly useful.

\section{References}

Baha el Din, S. M. and Salama, W. (1991) The catching of birds in North Sinai. Cambridge, UK: International Council for Bird Preservation. (ICBP Report no. 45).

BirdLife International (2004) Birds in Europe: population estimates, trends and conservation status. Cambridge, UK: BirdLife International.

del Hoyo, J., Elliott, A. and Sargatal, J. (1999) Handbook of the birds of the world, vol. 5: Barn-owls to hummingbirds. Barcelona, Spain: Lynx Edicions.

Goodman, S. M. and Meininger, P. L. (1989) The birds of Egypt. Oxford, UK: Oxford University Press.

Heldbjerg, H. and Fox, T. A. D. (2008) Long-term population declines in Danish trans-Saharan migrant birds. Bird Study 55: 267-279.
Magnin, G. (1991) Hunting and persecution of migratory birds in the Mediterranean regions Pp. 59-71 in T. Salathé, ed. Conserving migratory birds. Cambridge, UK: International Council for Bird Preservation.

McCulloch, M. N., Tucker, G. M. and Baillie, S. R. (1992) The hunting of migratory birds in Europe: a ringing recovery analysis. Ibis 134: 55-65.

Moreau, R. E. (1927) Quail. Bull. Zool. Soc. Egypt 1: 6-13.

Sanderson, F. J., Donald, P. F., Pain, D. R., Burfield, I. L. and van Bommel, F. P. J. (2006) Long-term population declines in AfroPalearctic migrant birds. Biol. Conserv. 131: 93-105.

Thaxter, C. B., Joys, A. C., Gregory, R. D., Baillie, S. R., and Noble, D. G. (2010) 
Hypotheses to explain patterns of population change among breeding bird species in England. Biol. Conserv. 143: 2006-2019.

Vickery, J. A., Ewing, S. R., Smith, K. W., Pain,

D. J., Bairlein, F., Skorpilová, J, and Gregory,

R. D. (2014) The decline of Afro-Palaearctic migrants and an assessment of potential causes. Ibis 156: 1-22.

Zuckerbrot, Y. D., Safriel, U. N. and Paz, U. (1980) Autumn migration of Quail Coturnix coturnix at the north coast of the Sinai Peninsula. Ibis 122: 1-14.

\section{PERRI EASON*}

Department of Biology, University of Louisville, Louisville, KY, USA.

\section{BASEM RABIA}

Nature Conservation Sector, Egyptian Environmental Affairs Agency, Cairo, Egypt.

\section{OMAR ATTUM}

Department of Biology, Indiana University Southeast, New Albany, IN, USA.

*Author for correspondence; email:perri.eason@louisville.edu

Received II September 2014; revision accepted 16 June 2015; Published online 23 November 2015 